\title{
Water mites (Acari, Hydrachnidia) of water bodies of the Krapiel River valley: interactions in the spatial arrangement of a river valley
}

\author{
Robert Stryjecki $^{2} \cdot$ Andrzej Zawal $^{1} \cdot$ Edyta Stępień $^{3} \cdot$ Edyta Buczyńska $^{2} \cdot$ \\ Paweł Buczyński $^{4} \cdot$ Stanisław Czachorowski $^{5} \cdot$ Magdalena Szenejko $^{6} \cdot$ \\ Przemysław Śmietana ${ }^{6}$
}

Received: 20 September 2015/ Accepted: 6 February 2016/Published online: 14 March 2016

(c) The Author(s) 2016. This article is published with open access at Springerlink.com

\begin{abstract}
The present study is a discussion of the interactions between different types of water bodies in the spatial arrangement of a river valley, taking into account landscape data. The Hydrachnidia assemblages in particular types of valley water bodies (oxbows, riparian pools, permanent ponds, flooded alder carrs, sedge marshes, and springs) are strongly influenced by the spatial arrangement of the water bodies in the landscape. Moreover, the formation of a fauna in a particular type of valley water body is also influenced by its origin. For example, the faunas of the oxbow lakes and riparian pools would have many characteristics in common, as these two types of water
\end{abstract}

Electronic supplementary material The online version of this article (doi:10.1007/s10201-016-0479-6) contains supplementary material, which is available to authorized users.

Handling editor: Jeremy Piggott.

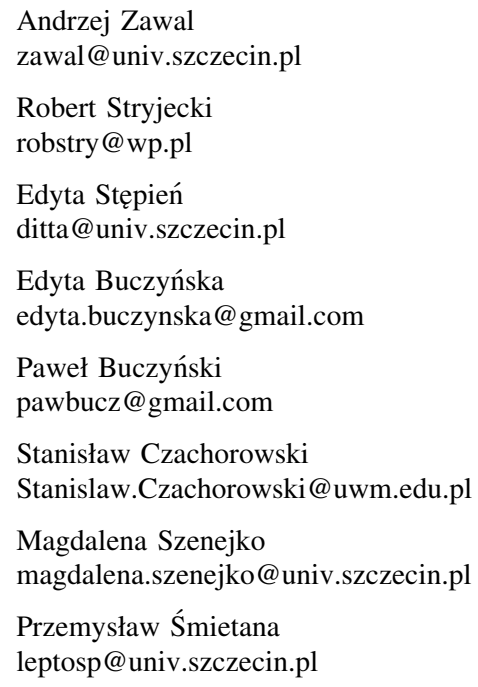
body can be characterized as originating in the river. As many as 61 species common to the valley water bodies and the Krapiel River were noted. In the interactions between the valley water bodies and the river, the direction of migration from the former to the latter was clearly predominant. Migration in the reverse direction, from the river to the valley water bodies, took place to a far lesser degree. CCA analysis of landscape variables showed the influences of certain landscape parameters on water mites. These should be regarded as indirect influences, but as a consequence of their effects, they influence the formation of specific types of Hydrachnidia assemblages.

Keywords River valley - Landscape variables - Spatial arrangement - Interactions between types of water bodies . Migration

1 Department of Invertebrate Zoology and Limnology, University of Szczecin, Wąska 13, 71-415 Szczecin, Poland

2 Department of Zoology, Animal Ecology and Wildlife Management, University of Life Sciences in Lublin, Akademicka 13, 20-950 Lublin, Poland

3 Department of Plant Taxonomy and Phytogeography, University of Szczecin, Wąska 13, 71-415 Szczecin, Poland

4 Department of Zoology, Maria Curie-Skłodowska University, Akademicka 19, 20-033 Lublin, Poland

5 Department of Ecology and Environmental Protection, Faculty of Biology, University of Warmia and Mazury in Olsztyn, Plac Łódzki 3, 10-727 Olsztyn, Poland

6 Department of Ecology and Environmental Protection, University of Szczecin, Wąska 13, 71-415 Szczecin, Poland 


\section{Introduction}

Most studies on the water mites of river valleys are limited to research on the rivers themselves, overlooking the water bodies of the floodplain and other water bodies in the river valley (Biesiadka 1970; Kowalik 1981; Kowalik and Biesiadka 1981; Bazan-Strzelecka 1986; Böttger and Hoerschelmann 1991; Cicolani and Di Sabatino 1991; Gerecke and Schwoerbel 1991; Meyer 1994; Böttger and Martin 1995; Cichocka 1996a; Martin 1996, 1997; Cichocka 2006; Stryjecki and Kowalczyk-Pecka 2013a; Zawal and Kowalik 2013; Kowalik et al. 2014). Focusing only on the fauna of the river usually does not allow for a complete interpretation of the composition of the fauna because it overlooks a number of factors which affect the river fauna while acting outside of the river itself, such as physiographic and geographic factors or factors acting at the scale of the landscape (van der Hammen and Smit 1996; Gerecke 2002; Stryjecki and Kowalczyk-Pecka 2013b; Zawal et al., unpublished data).

According to Žadin (quoted in Biesiadka 1974), oxbow lakes are an integral part of the river system because they are part of the former river channel. For this reason, it seems essential to conduct research on the fauna of river valleys considered as a whole, i.e., taking into account not only the river itself but also other water bodies situated in the river valley. As yet there have been only a few studies discussing the Hydrachnidia of river valleys in this manner (Biesiadka 1974, 1979; Biesiadka et al. 2004; Stryjecki 2009, 2010; Stryjecki and Kowalczyk-Pecka 2013b).

In the case of water mites, treating the river valley as a whole is justified by the fact that the life cycle of these organisms has a terrestrial stage. The developmental cycle of most water mite species includes a parasitic stage occurring outside the aquatic environment-the larvae parasitize flying insects. Adult forms of insects are used both as a food source and as a means of spreading water mites (Di Sabatino et al. 2000; Smith et al. 2001). When we consider the fact that part of the life cycle of water mites takes place outside the aquatic environment, it should be assumed that the formation of particular Hydrachnidia assemblages in different types of water body may also be influenced by factors acting outside the aquatic environment and affecting the hosts of water mite larvae, i.e., flying insects (e.g., Chironomidae).

The terrestrial environment is usually overlooked in studies of aquatic organisms, although it can have a significant effect on the formation of assemblages of various taxa of aquatic organisms (Delettre et al. 1992, Delettre and Morvan 2000; Galic et al. 2013). Most studies on the effect of landscape structure on the biodiversity and spatial distribution of various organisms deal mainly with terrestrial organisms (Delettre 2005). Yet the organization of the landscape does not only affect terrestrial organisms; the structure of the landscape and how it is used influence aquatic environments and therefore the invertebrate assemblages inhabiting them (Richards and Host 1994; Richards et al. 1996). For example, Delettre and Morvan (2000) studied the effect of terrestrial landscape structure on the spatial distribution of adult Chironomidae flying out of water bodies. The authors found that the terrestrial environment has a strong effect on the population dynamics and taxonomic composition of aquatic Chironomidae (Delettre and Morvan 2000). This demonstration of the effect of landscape structure on Chironomidae suggests that factors affecting these insects also affect water mite assemblages inhabiting various types of water bodies via the parasite-host relationships of these two groups of organisms.

As mentioned above, most studies on the Hydrachnidia of river valleys focus on the rivers themselves, while there are few dealing with both rivers and water bodies of the river valley at the same time. As yet, such research has never been supported by landscape characterization. The present study is an attempt to discuss-more extensively than in the available literature-interactions in the spatial arrangement of the river valley.

The following suppositions were made in the study:

1. It was postulated that apart from factors acting within the aquatic environment, water mite fauna may also be affected by factors acting in the terrestrial environment, on the scale of the landscape (Fig. 1). These dependencies are represented in Fig. 1 by vertical arrows illustrating the effect of landscape characteristics on both the biotic elements of the environment and abiotic elements (e.g., the presence of particular types of water body). At this level, the level of the landscape, it is most difficult to find correlations between the variables analyzed and Hydrachnidia assemblages, due to the vast complexity of the system analyzed.

2. The Hydrachnidia assemblages in particular types of valley water bodies are strongly influenced by the spatial arrangement of the water bodies in the landscape. It was postulated that besides the type of water body (riparian pools, sedge marshes, or permanent ponds), the composition of the fauna is influenced by the proximity of other types of water body, as migration of fauna via flying insects takes place between water bodies (Fig. 1, horizontal arrows).

3. The formation of fauna in particular types of valley water bodies is influenced by their origin. It was posited that the faunas of the oxbow lakes and riparian pools would have many characteristics in common, as these two types of water body can be characterized as 
Fig. 1 Diagram of the network of interactions of various environmental factors in catchments. Horizontal block arrows show the interactions between the valley water bodies and the river. Bigger arrows show a greater degree of migration of the fauna, smaller arrows show a lesser degree of migration of the fauna. Vertical arrows illustrate the effect of landscape characteristics on both the biotic and abiotic elements of the environment

\section{Type of landscape (landscape features)}

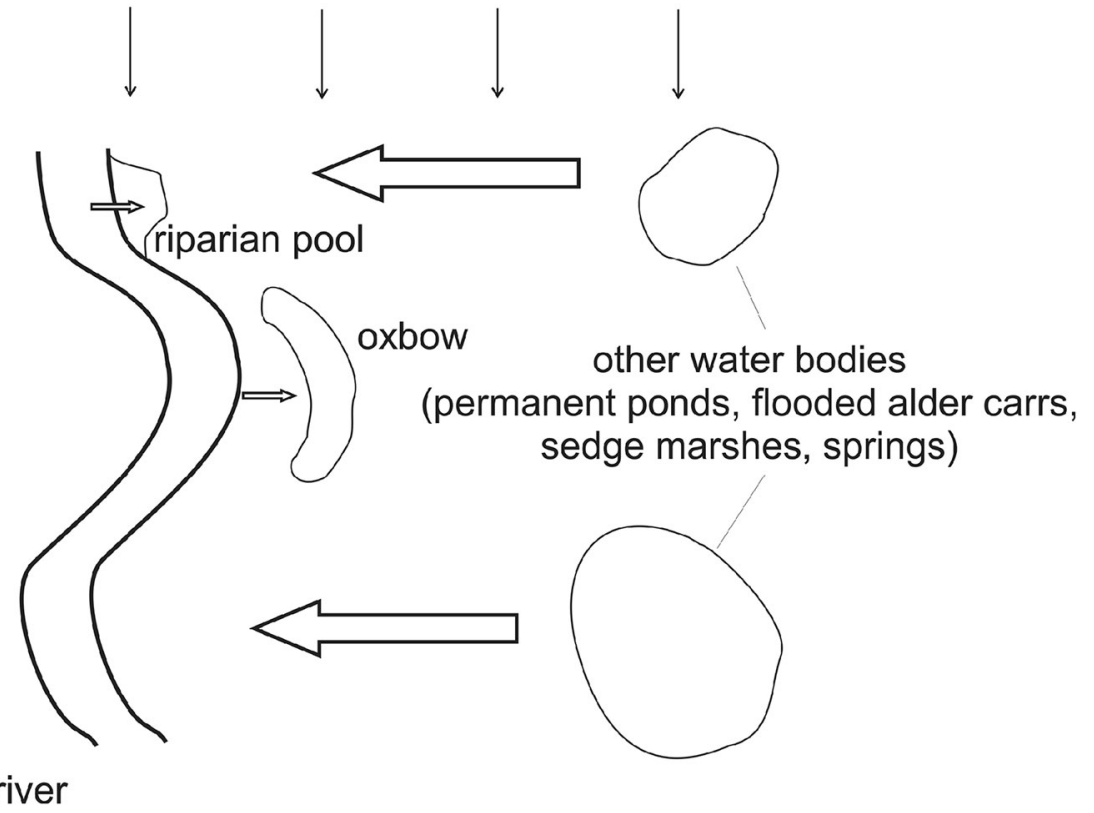

originating in the river. Due to this origin, as well as their close proximity to the river, similar mechanisms influencing the formation of a specific type of fauna act on these two types of water body (e.g., more migration of fauna to and from the river than in the case of other water bodies Fig. 1).

4. Valley water bodies and the river influence one another via migration of fauna. It was postulated that migration takes place to a much greater degree in the direction from the valley water bodies to the river (large horizontal arrows in Fig. 1), and to a much lesser degree in the reverse direction (smaller horizontal arrows in Fig. 1).

The aim of the study was to verify the suppositions presented above.

The question of the effect of landscape structure and other environmental and habitat factors on the water mites of the Krapiel River will be presented in a separate paper (Zawal et al., unpublished data).

\section{Materials and methods}

The river valley was divided into 13 segments (13 catchments)-K1-K14 (without K5-the position assumed at the beginning of the researches, but dropped during the study), for which various landscape parameters were determined. Analysis of the landscape was based on buffer zones and catchments assigned to each sampling site (K1-K14) (Fig. 2). The buffer zone was marked out as a circle around the site with a radius of
$500 \mathrm{~m}$. The catchment basin of the Krapiel River was divided into segments corresponding to the sampling sites, and in this manner a catchment area was assigned to each site.

Analysis of the spatial structure of the buffer zones and catchments was based on a set of landscape metrics calculated using the TNTmips software from MicroImages. Classification was based on data from Landsat TM7 28-052003. Land cover classes were determined according to the Corine classification. Buffer zones with a radius of $500 \mathrm{~m}$ from the sampling point were marked out using GPS.

The following measures and indices were used to analyze the landscape structure: (1) measurements of patch area-area (AREA); (2) measurements of patch density and size-number of patches (NUMP), mean patch size (MPS), median patch size (MEDPS), patch size standard deviation (PSSD), and patch density (PD); (3) boundary measurements - total edge length (TE), edge density (ED), and mean edge length (MTE); (4) shape measurementsmean shape index (MSI), mean patch fractal dimension (MPFD), and sum of patch shape indices (SUM); (5) diversity and distribution indices-mean distance to nearest neighbor (MNN), interspersion and juxtaposition index (IJI), Shannon's patch diversity index (SDI), the Shannon evenness index (SEI), catchment area from the sources (a cat cu), catchment area (a cat), length of catchment boundaries, roughness $(\mathrm{Ra})$, contagion $(\mathrm{Cr})$, river gradient (river fa), distance from source (d source), area ( $a$ ) of each patch (forests, fields, swamps, built-up areas, meadows, shrubs, wasteland, and water bodies), and distance from the river $(d)$ of each patch (forests, agricultural areas, swamps, 
Fig. 2 Locations of the sampling sites: $A$ rivers, $B$ lakes and fish ponds, $C$ forests, $D$ -

$I$ sampling sites (numbers inside indicate the number of localities), $D$ permanent ponds, $E$ oxbows, $F$ sedge marshes, $G$ riparian pools, $H$ flooded alder carrs, $I$ springs, $J$ number of localities

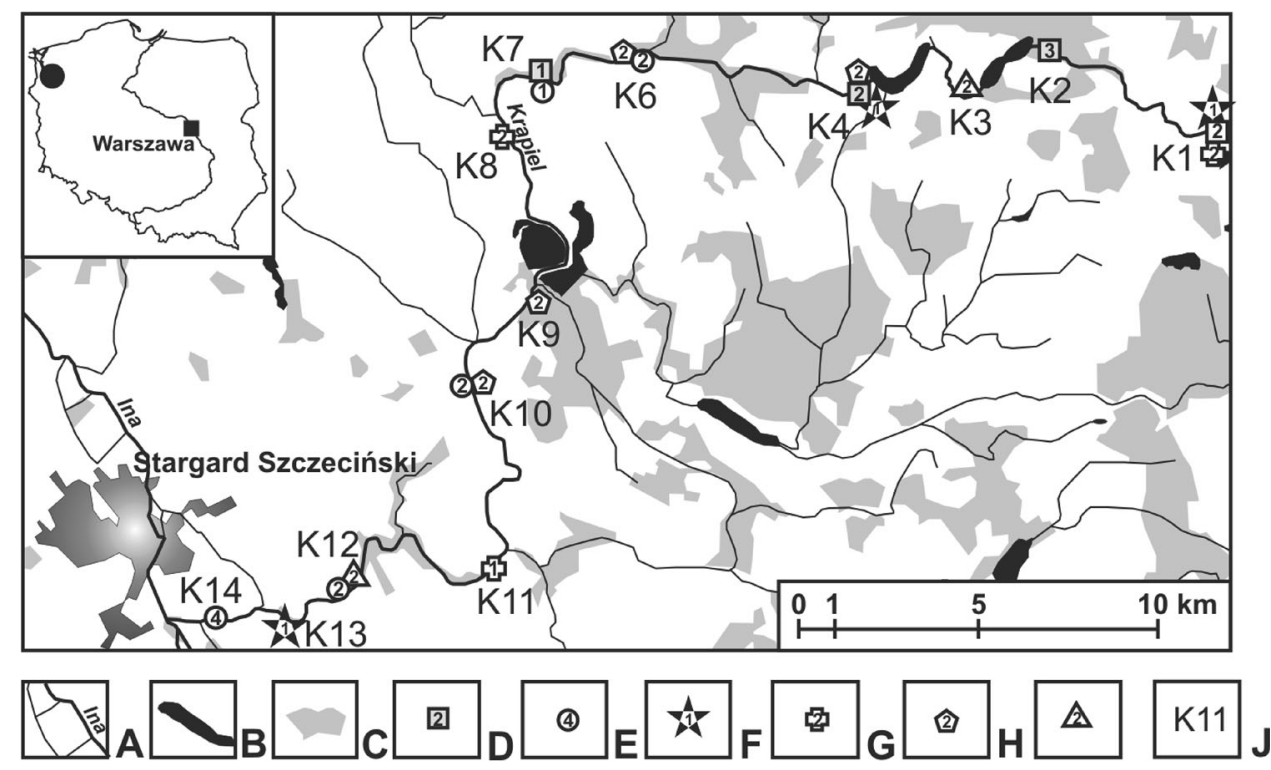

built-up areas, meadows, shrubs, wasteland, and water bodies); (6) characteristics of particular patches (forests, fields, swamps, built-up areas, meadows, shrubs, wasteland, and water bodies) in the buffer zones: area (CA), mean patch size (MCA), mean shape index (MSI), patch density (PD), ratio of area to boundary length (L/D).

After the data had been analyzed, only landscape parameters which were not collinear were selected: PSSD, SEI, MTE, SUM, MEDPS, PD, MPS, SDI, TE, Ra, Cr, river fa, a cat $\mathrm{cu}$, a cat, a river, a wast, $\mathrm{d}$ source, $\mathrm{d}$ field, $\mathrm{d}$ build, d mead, d st wat, d fores, d shrub, d marsh, CA, MCA, MSI, PD, L/D.

Biological samples were collected at monthly intervals from standing water bodies and springs in the valley of the small lowland River Krapiel (north-western Poland) (Fig. 2). Field work was carried out from April to October 2010. Stations were located in the following types of water bodies: small permanent ponds (8), oxbow lakes (11), flooded alder carrs (8), sedge marshes (4), riparian pools (5), and springs (4) (Fig. 2). Detailed characteristics of the investigated water bodies are given in Online Resources 1 and 3 in the Electronic supplementary material (ESM). The different number of water bodies in each category are due to differences in their frequency of occurrence in the valley of the Krapiel. Three subsamples were collected on each sampling occasion for variability analyses. Sampling used a square metal frame, which isolated a $0.5 \mathrm{~m}^{2}$ area of field. Inside the frame, 10 energetic sweeps were performed by hand net. A total of 279 samples were collected. The number of samples taken in particular types of water bodies varied due to the number of water bodies and their degree of permanence; in permanent water bodies, samples were taken each month of the study, whereas samples were taken in astatic water bodies for as long as they were functioning. Due to the unequal number of samples, in addition to absolute data (total individuals), the average number of individuals per sample is given as well. Adult water mites were identified to species level, and larvae and deutonymphs to genus level.

Similarities between parameters were determined using BIODIVERSITY PRO v.2 software (McAleece et al. 1997). The Euclidian distance formula was used for catchment parameters, the Bray-Curtis formula for faunal similarities in the water bodies of the river valley, and Jaccard's formula was used to estimate the similarities between the faunas of these water bodies and that of the River Krąpiel.

The following environmental parameters were measured: insolation (insolati., \%), overgrowth with aquatic vegetation (plants, scale from 0 to 5 , where 0 means no plants and 5 means totally overgrown by plants), water temperature (temp., ${ }^{\circ} \mathrm{C}$ ), water $\mathrm{pH}(\mathrm{pH})$, total hardness (hardness, mg $\mathrm{CaCO}_{3} / \mathrm{dm}^{3}$ ), conductivity (cond., $\mu \mathrm{S}$ ), turbidity (turbidit., $\left.\mathrm{mg} / \mathrm{dm}^{3}\right)$, oxygen content $\left(\mathrm{O}_{2}, \mathrm{mg} / \mathrm{dm}^{3}\right)$, ammonia nitrogen $\left(\mathrm{NH}_{4}, \mathrm{mg} / \mathrm{dm}^{3}\right)$, nitrate nitrogen $\left(\mathrm{NO}_{3}\right.$, $\left.\mathrm{mg} / \mathrm{dm}^{3}\right)$, phosphates $\left(\mathrm{PO}_{3}, \mathrm{mg} / \mathrm{dm}^{3}\right)$, ferric ions $(\mathrm{Fe}, \mathrm{mg} /$ $\mathrm{dm}^{3}$ ), BOD5, proportion of mineral sediment (mineral, $\%$ ), proportion of organic sediment (organic, \%), mean sediment grain size $(M, \mathrm{~mm})$, and sediment sorting $(W)$. Average values of physicochemical parameters of water and sediment properties in particular habitats are given in Online Resource 2 in the ESM. Insolation was measured with a CEM DT-1309 light meter. Water parameters, i.e., temperature, $\mathrm{pH}$, electrolytic conductivity, and dissolved oxygen content, were measured with an Elmetron CX-401 multiparametric sampling probe, water flow using a 
SonTek acoustic FlowTracker flowmeter, $\mathrm{BOD}_{5}$ by Winkler's method, and the remaining parameters with a Slandi LF205 photometer. Three measurements were performed on each sampling occasion, and the median was used for further analysis.

Bottom sediment analysis included determinations of grain size and the organic and mineral matter contents. The Krumbein scale was used in the granulometric analysis, with grain size $(d)$ in mm expressed in phi units $(\varphi)$, where $\varphi=-\log _{2} d[\mathrm{~mm}]$.

The following calculations were performed: mean grain size (graphic arithmetic mean), i.e., mean diameter $M=(\varphi$ $16+\varphi 50+\varphi 84$ ) $/ 3$; and sediment sorting (graphic standard deviation), which is a measure of the dispersion of grain diameter values: $W=[(\varphi 84-\varphi 16) / 4]+[(\varphi 95-$ $\varphi$ 5)/6.6] (Myślińska 2001).

Individual sediment samples were freeze-dried using an Alpha 1-2 LD Plus freeze dryer (Christ), and then organic matter was removed from each sample by heating the sample in a Nabertherm furnace at $550{ }^{\circ} \mathrm{C}$ to obtain a solid mass. This allowed the percentages of mineral and organic matter to be determined.

\section{Results}

\section{Landscape characteristics of catchments}

Agroecosystems dominate the valley of the Krapiel, and within these agroecosystems the largest area is occupied by arable land. On the basis of the results pertaining to the land-use structure of the Krapiel valley, which were obtained in a GIS-based work, a specific type of landscape was assigned to each catchment (Table 1). A homogeneous landscape type-agricultural-was assigned to catchments K8, K10, and K12-14. The remaining catchments had a mixed type of landscape or a mosaic of landscapes (Table 1).

Figure 3 presents a dendrogram grouping the catchments on the basis of landscape parameters. Three clusters can be seen. The first cluster consists of catchments K8, K10, K12, K13, and K14. The common feature of those catchments is that their landscape type is agricultural (Table 1). The highest similarity within this aggregation was found between catchments $\mathrm{K} 8-\mathrm{K} 10$ and $\mathrm{K} 1-\mathrm{K} 13$ (Fig. 3). The second cluster includes catchments K3, K4, $\mathrm{K} 6, \mathrm{~K} 7$, and K11. These catchments were characterized by a mixed type of landscape, with dominance of farmland (Table 1). The highest similarity within this aggregation was noted between catchments K7 and K11 (Fig. 3). The third cluster contains catchments $\mathrm{K} 1, \mathrm{~K} 2$, and $\mathrm{K} 9$. The greatest similarity within this aggregation was observed
Table 1 Landscape types in each catchment

\begin{tabular}{ll}
\hline Catchment & Landscape type \\
\hline K1 & Mixed, with dominance of forests \\
K2 & Mosaic-meadow, forest, agricultural \\
K3 & Mixed, with dominance of forests \\
K4 & Mixed, with dominance of farmland \\
K6 & Mixed, with dominance of farmland \\
K7 & Mixed, with dominance of farmland \\
K8 & Agricultural \\
K9 & Mosaic-meadow, forest, agricultural \\
K10 & Agricultural \\
K11 & Mixed, with dominance of farmland \\
K12 & Agricultural \\
K13 & Agricultural \\
K14 & Agricultural \\
\hline
\end{tabular}

between catchments K2 and K9 (Fig. 3), as both were of mosaic type (Table 1).

\section{Hydrachnidia fauna}

In the water bodies situated in the valley of the River Krapiel, a total of 1581 water mite individuals were caught (923 females, 490 males, 164 deutonymphs, and 4 larvae), belonging to 88 species (Table 2). The group of dominants (dominance $>5 \%$ ) comprised Piona coccinea (18.1\%), Piona nodata (12.6\%), Hydryphantes tenuipalpis (8.3\%), Tiphys ornatus (7.1\%), Arrenurus maculator (6.4\%), Arrenurus conicus (5.9\%), and Tiphys ensifer (5.6\%).

Differences between water body types were found in the number of individuals and species caught as well as in the dominance structure. In terms of absolute data (total individuals caught), the most individuals and species were caught in the oxbows (411 individuals, 55 species). The fewest individuals were found in the flooded alder carrs (139 individuals). The fewest species were caught in the springs (18 species) (Table 2). A very high (0.91), statistically significant $(p<0.05)$ correlation was found between the number of species recorded and the number of individuals in particular types of water bodies.

Taking into account relative data (mean abundance of individuals per sample), the diversity of fauna varied with the type of water body. The richest fauna was observed in the springs, where the mean number of individuals per sample was highest (21.1 individuals). A large number of water mites was also noted in the samples from the sedge marshes (on average 16.4 individuals/sample). In the other types of water body, the mean number of individuals per sample showed little variation, and was markedly lower than in the springs and sedge marshes, ranging from 4.6 to 5.5 . 
Fig. 3 Similarities between the catchments, estimated on the basis of landscape parameters

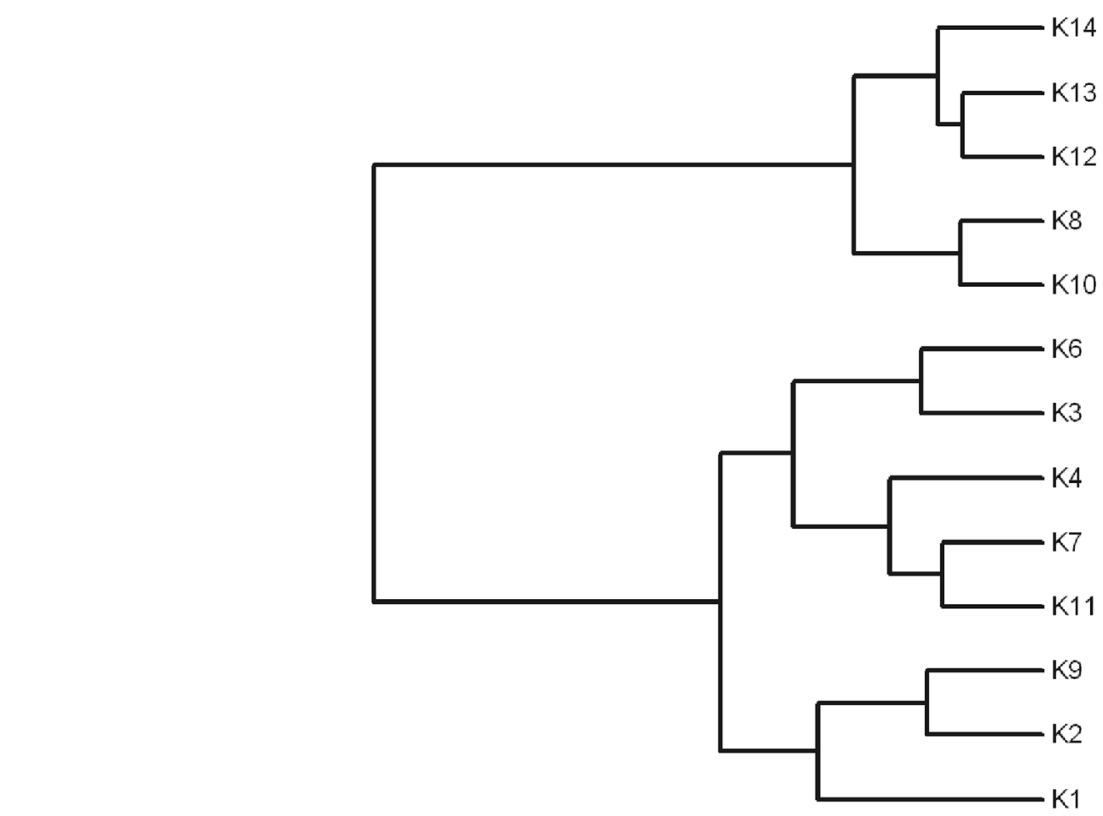

97, \% Similarity
Figure 4 presents similarities between the faunas of different types of water bodies. In the dendrogram, we can see a tendency to group water bodies from more astatic to more permanent and from more connected to less connected with the river. The highest similarity $(50.8 \%)$ was noted between the Hydrachnidia assemblages inhabiting the oxbows and riparian pools. Fairly high similarity of fauna $(42.1 \%)$ was also observed between the riparian pools and the permanent ponds. Springs and sedge marshes had the least similar faunas $(3.2 \%)$.

The fauna of the valley water bodies and the fauna of the river were $42.9 \%$ similar (qualitative similarity, Jaccard's formula) (Zawal et al., unpublished data). There were 61 species common to the valley water bodies and the Krapiel River. The highest qualitative faunal similarity was noted between the fauna of the river and that of the oxbows (33.1\%, 39 species in common), and the lowest between the river and the springs (9.9\%, 12 species in common). More species in common were noted for the valley water bodies and the lentic zone of the river ( 52 species) than for the lotic and lentic zones of the river itself ( 49 species in common).

Figure 5 presents faunal similarities between assemblages of Hydrachnidia caught in particular catchments. Two large clusters are visible in the dendrogram. The first cluster groups the faunas of water bodies situated in catchments $\mathrm{K} 1, \mathrm{~K} 2, \mathrm{~K} 8, \mathrm{~K} 10, \mathrm{~K} 4$, and $\mathrm{K} 9$. Within this cluster, the highest similarity $(49.7 \%)$ was noted between the faunas of catchments K8 and K10. High similarity was also noted between the faunas of catchments $\mathrm{K} 2$ and $\mathrm{K} 8$
(44.7\%). The second cluster groups together the faunas of water bodies located in catchments K6, K7, K13, and K14. Within this cluster, the highest similarity was noted between the faunas of catchments K13 and K14 (37.0\%). The highest degree of individuality (distinctiveness of fauna) was observed in the faunas of catchments $\mathrm{K} 3$ and K11.

DCA analysis of the distributions of sampling sites and water mite species showed that the length of the gradient represented by the first ordination axis was 5.57, which made it possible to conduct direct ordination analyses of the CCA type to determine the relationships between occurrence of species and the environmental parameters considered for the water bodies of the Krapiel River valley (ter Braak 1986; ter Braak and Verdonschot 1995).

The CCA analysis of the effect of elements of the catchment on the distribution of water mites took into account all parameters that did not exhibit collinearity. Only catchment surface area (a cat), distance from meadows to river ( $d$ mead), distance from shrubs to river ( $d$ shrub), and distance from wasteland to river (d wast.) were statistically significant $(p \leq 0.05)$ (Fig. 6). The variables used in the ordination explain $42.0 \%$ of the total variance.

In the CCA analysis for the dependence of water mite distribution on the characteristics of buffer zones, many variables were found to be collinear; only the 9 variables that were not collinear were used for further analysis. These were PSSD, SEI, MTE, SUM, MEDPS, PD, MPS, SDI, TE, MSI, ED, NUMP, and Cr (Fig. 7). Of these parameters, only the first three were statistically significant 
Table 2 Species composition and number of individuals of each species of water mite collected in the water bodies located in the valley of the Krąpiel River

\begin{tabular}{|c|c|c|c|c|c|c|c|c|c|}
\hline No. & Species & Abbr. & A & $\mathrm{B}$ & $\mathrm{C}$ & $\mathrm{D}$ & $\mathrm{E}$ & $\mathrm{F}$ & Total \\
\hline 1 & Hydrachna conjecta Koen. & Hyd con & 1 & 1 & & & & & 2 \\
\hline 2 & Hydrachna crassipalpis Piers. & Hyd cra & & 1 & & & & & 1 \\
\hline 3 & Hydrachna cruenta O. F. Müll. & Hyd cru & 1 & & & & & & 1 \\
\hline 4 & Hydrachna globosa (Geer) & Hyd glo & & & 2 & & & & 2 \\
\hline 5 & Hydrachna goldfeldi Thor & Hyd gol & & & 1 & & & & 1 \\
\hline 6 & Hydrachna incognita (Vajnštejn) & Hyd inc & & 4 & & & & & 4 \\
\hline 7 & Eylais extendens (O. F. Müll.) & Eyl ext & 1 & & & & & & 1 \\
\hline 8 & Eylais hamata Koen. & Eyl ham & & & & 1 & & & 1 \\
\hline 9 & Piersigia intermedia Williams. & Pie int & 2 & & & & & & 2 \\
\hline 10 & Euthyas truncata (Neum.) & Eut tru & & & 4 & & & & 4 \\
\hline 11 & Parathyas barbigera Viets & Par bar & 1 & 1 & & & 4 & 1 & 7 \\
\hline 12 & Parathyas bruzelii Lundblad & Par bru & & 1 & & & & & 1 \\
\hline 13 & Parathyas dirempta Koen. & Par dir & 1 & 7 & 2 & 2 & 1 & 2 & 15 \\
\hline 14 & Parathyas pachystoma Koen. & Par pac & 3 & 4 & & & 2 & 3 & 12 \\
\hline 15 & Parathyas palustris Koen. & Par pal & 1 & 1 & & 1 & & 7 & 10 \\
\hline 16 & Parathyas thoracata (Piers.) & Par tho & & 1 & & & & & 1 \\
\hline- & Parathyas sp. Lundblad & Par sp. & 1 & 2 & & & & 1 & 4 \\
\hline 17 & Thyasides dentatus (Thor) & Thy den & & & 1 & & & & 1 \\
\hline 18 & Hydryphantes crassipalpis Koen. & Hy cras & 1 & & & 2 & & & 3 \\
\hline 19 & Hydryphantes hellichi Thon & Hy hell & 2 & & & & & & 2 \\
\hline 20 & Hydryphantes octoporus Koen. & Hy octo & 1 & & & 3 & & & 4 \\
\hline 21 & Hydryphantes peroviensis Udalzow & Hy pero & 1 & & & & & & 1 \\
\hline 22 & Hydryphantes planus Thon & Hy plan & & & & & 1 & & 1 \\
\hline 23 & Hydryphantes ruber (Geer) & Hy rube & 2 & 15 & 4 & 2 & 5 & & 28 \\
\hline 24 & Hydryphantes tenuipalpis Thon & Hy tenu & 11 & 45 & 6 & 22 & 12 & & 96 \\
\hline- & Hydryphantes sp. Koch & Hy sp. & 1 & 5 & 3 & & & & 9 \\
\hline- & Hydryphantoidea & Hydryph & 3 & & & & & & 3 \\
\hline 25 & Protzia invalvaris Piers. & Pro inv & & & & & 1 & & 1 \\
\hline 26 & Sperchon compactilis Koen. & Spe com & & & & 1 & & & 1 \\
\hline 27 & Sperchon squamosus Kram. & Spe squ & & & & & & 9 & 9 \\
\hline 28 & Sperchon thienemanni Koen. & Spe thi & & & & & & 11 & 11 \\
\hline 29 & Lebertia minutipalpis Viets & Leb min & & & & & & 3 & 3 \\
\hline 30 & Lebertia rivulorum Viets & Leb riv & 1 & & & & & & 1 \\
\hline 31 & Limnesia fulgida Koch & Lim ful & 1 & & & & & & 1 \\
\hline 32 & Limnesia maculata (O. F. Müll.) & Lim mac & 6 & & 1 & & & & 7 \\
\hline 33 & Limnesia undulata (Müller) & Lim und & 1 & & & & & & 1 \\
\hline 34 & Limnesia undulatoides Davids & Li undu & & & 2 & & 1 & & 3 \\
\hline 35 & Hygrobates longipalpis (Hermann) & Hyg lon & 5 & & 8 & & 3 & 2 & 18 \\
\hline 36 & Hygrobates setosus Besseling & Hyg set & 1 & & & & & & 1 \\
\hline 37 & Neumania limosa (Koch) & Neu lim & 1 & & & & & & 1 \\
\hline 38 & Piona alpicola (Neum.) & Pio alp & & 3 & & 1 & & & 4 \\
\hline 39 & Piona carnea (Koch) & Pio car & & & & & 6 & & 6 \\
\hline 40 & Piona clavicornis (O. F. Müll.) & Pio cla & 1 & & & & 55 & & 56 \\
\hline 41 & Piona coccinea $(\mathrm{Koch})$ & Pio coc & 19 & & 171 & 15 & 8 & & 213 \\
\hline 42 & Piona conglobata (Koch) & Pio con & & & 1 & & & & 1 \\
\hline 43 & Piona imminuta (Piers.) & Pio imm & & & 1 & & & & 1 \\
\hline 44 & Piona neumani (Koen.) & Pio neu & 3 & & 11 & 1 & & & 15 \\
\hline 45 & Piona nodata (O. F. Müll.) & Pio nod & 21 & 75 & 4 & 33 & 14 & & 147 \\
\hline
\end{tabular}


Table 2 continued

\begin{tabular}{|c|c|c|c|c|c|c|c|c|c|}
\hline No. & Species & Abbr. & A & $\mathrm{B}$ & $\mathrm{C}$ & $\mathrm{D}$ & $\mathrm{E}$ & $\mathrm{F}$ & Total \\
\hline 46 & Piona nodata laminata (Thor) & Pio n la & & 36 & 1 & 1 & 3 & 9 & 50 \\
\hline 47 & Piona obturbans (Piers.) & Pio obt & 5 & & & & & & 5 \\
\hline 48 & Piona paucipora (Thor) & Pio pau & 3 & & 1 & & & & 4 \\
\hline 49 & Piona pusilla (Neum.) & Pio pus & 1 & 6 & & & & & 7 \\
\hline 50 & Piona rotundoides (Thor) & Pio rot & & 3 & & & & & 3 \\
\hline 51 & Piona variabilis (Koch) & Pio var & 6 & & 5 & & & & 11 \\
\hline- & Piona sp. Koch & Pio sp. & 11 & 14 & 6 & 12 & 8 & & 51 \\
\hline 52 & Hydrochoreutes ungulatus (Koch) & Hyd ung & 1 & & & & & & 1 \\
\hline 53 & Hydrochoreutes krameri Piers. & Hyd kra & & & 1 & & & & 1 \\
\hline 54 & Pionopsis lutescens (Hermann) & Pio lut & 2 & 28 & & 7 & & & 37 \\
\hline 55 & Tiphys bullatus (Thor) & Tip bul & & & & & 1 & & 1 \\
\hline 56 & Tiphys ensifer (Koen.) & Tip ens & 27 & 17 & 14 & 7 & 3 & & 68 \\
\hline 57 & Tiphys latipes (O. F. Müll.) & Tip lat & 13 & 5 & 10 & 7 & & & 35 \\
\hline 58 & Tiphys ornatus Koch & Tip orn & 38 & 2 & 1 & 44 & & & 85 \\
\hline 59 & Tiphys scaurellus Tuzovskij & Tip scau & & & & & & 1 & 1 \\
\hline 60 & Tiphys scaurus (Koen.) & Tip sca & 2 & & & 6 & & 1 & 9 \\
\hline 61 & Tiphys torris (O. F. Müll.) & Tip tor & & & 1 & 4 & & & 5 \\
\hline- & Tiphys sp. Koch & Tip sp. & 7 & & & 6 & & & 13 \\
\hline 62 & Forelia variegator $(\mathrm{Koch})$ & For var & 2 & & & 3 & & & 5 \\
\hline- & Pionidae (Thor.) & Pioni & 10 & 1 & 7 & 7 & 4 & & 29 \\
\hline 63 & Wettina podagrica (Koch) & Wet pod & 1 & & & & & & 1 \\
\hline 64 & Mideopsis willmanni (Viets) & Mid wil & & & & & & 2 & 2 \\
\hline 65 & Arrenurus affinis Koen. & Arr aff & 5 & & & & & & 5 \\
\hline 66 & Arrenurus batillifer Koen. & Arr bat & 8 & & 2 & 1 & 1 & & 12 \\
\hline 67 & Arrenurus bicuspidator Berlese & Arr bic & 2 & & & & & & 2 \\
\hline 68 & Arrenurus bifidicodulus Piers. & Arr bif & 3 & 4 & & & 1 & & 8 \\
\hline 69 & Arrenurus bisulcicodulus Piers. & Arr bis & 2 & 2 & & 1 & & & 5 \\
\hline 70 & Arrenurus buccinator (O. F. Müll.) & Arr buc & 3 & & & & & & 3 \\
\hline 71 & Arrenurus claviger Koen. & Arr cla & 1 & & 1 & & & & 2 \\
\hline 72 & Arrenurus conicus Piers. & Arr con & & & & & & 93 & 93 \\
\hline 73 & Arrenurus cuspidator (O. F. Müll.) & Arr cus & 29 & & 1 & 3 & & 3 & 36 \\
\hline 74 & Arrenurus cylindratus Piers. & Arr cyl & & & & 1 & & 2 & 3 \\
\hline 75 & Arrenurus fimbriatus Koen. & Arr fim & 14 & 3 & 2 & 1 & & & 20 \\
\hline 76 & Arrenurus globator (O. F. Müll.) & Arr glo & & & 3 & & & & 3 \\
\hline 77 & Arrenurus inexploratus Viets & Arr ine & 33 & 15 & & 16 & 3 & & 67 \\
\hline 78 & Arrenurus integrator (O. F. Müll.) & Arr int & 8 & 3 & 1 & 7 & & 1 & 20 \\
\hline 79 & Arrenurus knauthei Koen. & Arr kna & & & & 2 & & 1 & 3 \\
\hline 80 & Arrenurus maculator (O. F. Müll.) & Arr mac & 61 & 1 & 14 & 3 & 1 & & 80 \\
\hline 81 & Arrenurus mediorotundatus Thor & Arr med & & 1 & & 2 & & 3 & 6 \\
\hline 82 & Arrenurus mиelleri Koen. & Arr mue & 1 & & & & 1 & & 2 \\
\hline 83 & Arrenurus nodosus Koen. & Arr nod & 1 & & & & & & 1 \\
\hline 84 & Arrenurus pugionifer Koen. & Arr pug & 7 & 5 & & 13 & & & 25 \\
\hline 85 & Arrenurus tetracyphus Piers. & Arr tet & 1 & & & & & & 1 \\
\hline 86 & Arrenurus truncatellus (O. F. Müll.) & Arr tru & 4 & & & 12 & & & 16 \\
\hline 87 & Arrenurus tubulator (O. F. Müll.) & Arr tub & & 1 & 2 & 11 & & & 14 \\
\hline 88 & Arrenurus virens Neuman & Arr vir & 1 & & & & & & 1 \\
\hline \multirow[t]{2}{*}{-} & Arrenurus sp. Duges & Arr sp. & 4 & & 1 & 2 & & 4 & 11 \\
\hline & TOTAL specimens & & 411 & 313 & 296 & 263 & 139 & 159 & 1581 \\
\hline
\end{tabular}


Table 2 continued

\begin{tabular}{rlrrrrrrrr}
\hline No. & Species & Abbr. & A & B & C & D & E & F & Total \\
\hline & Species & 55 & 29 & 31 & 33 & 21 & 18 & 88 \\
\hline
\end{tabular}

$A$ oxbows, $B$ permanent ponds, $C$ sedge marshes, $D$ riparian pools, $E$ flooded alder carrs, $F$ springs

Fig. 4 Faunal similarities between water body types: $o x$ oxbows, $p p$ permanent ponds, $s m$ sedge marshes, $r p$ riparian pools, fac flooded alder carrs, $s p$ springs

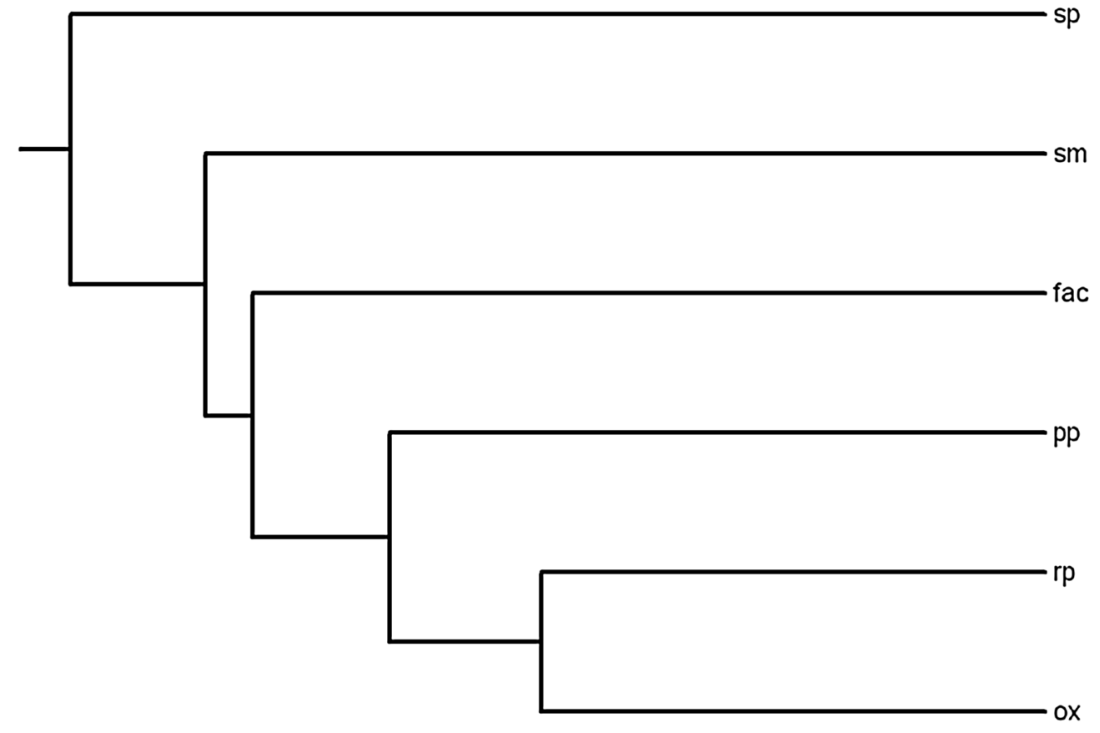

0. $\%$ Similarity

50. 100

$(p \leq 0.05)$. The variables used in the ordination explain $35.0 \%$ of the total variance.

Many variables were also found to be collinear in the CCA analysis for the dependence of water mite distribution on the characteristics of particular patches in the buffer zones; only variables that were not collinear were used for further analysis. These were the total surface area of patches of a given class: densely built-up areas-CA(1), meadows and pastures- $\mathrm{CA}(9)$, and broadleaf forests$\mathrm{CA}(11)$; mean patch size: lightly built-up areas-MCA(2), orchards and plantations-MCA(8), and willow thicketsMCA(15); mean shape index: willow thickets-MSI (15); patch density: densely built-up areas-PD(1) and thoroughfares- $\mathrm{PD}(3)$; and ratio of area to boundary length: orchards and plantations-L/D(8). Statistically significant parameters $(p \leq 0.05)$ are shown in bold and underlined in the figure (Fig. 8). The variables used in the ordination explain $42.2 \%$ of the total variance.

Figure 9 presents the relationships between the physicochemical parameters of the water and Hydrachnidia fauna. $\mathrm{NO}_{3}, \mathrm{NH}_{4}, \mathrm{Fe}$, hardness, temperature, organic content, insolation, and sediment sorting were statistically significant. Group 2 comprises species that were found to be associated with water temperature. This group consists almost exclusively of species associated with astatic vernal pools. Group 3 comprises mainly small water body species characteristic of permanent eutrophic ponds, i.e., water bodies with well-developed aquatic vegetation, a high level of nutrients, and a muddy bottom. Group 1 comprises water mite species typical of springs. These are associated with habitats with high Fe content and a wellsorted substrate.

\section{Discussion}

A total of 88 water mite species were found in the water bodies situated in the valley of the River Krapiel, and 116 in the river itself (Zawal et al., unpublished data). In the river and the valley water bodies combined, 142 Hydrachnidia species were recorded. Considering that the Krapiel is a small lowland river (70 km in length) and its valley is narrow and deeply incised, with poorly developed floodplains, which limits the possibility of the formation of 
Fig. 5 Faunal similarity between Hydrachnidia assemblages in particular catchments

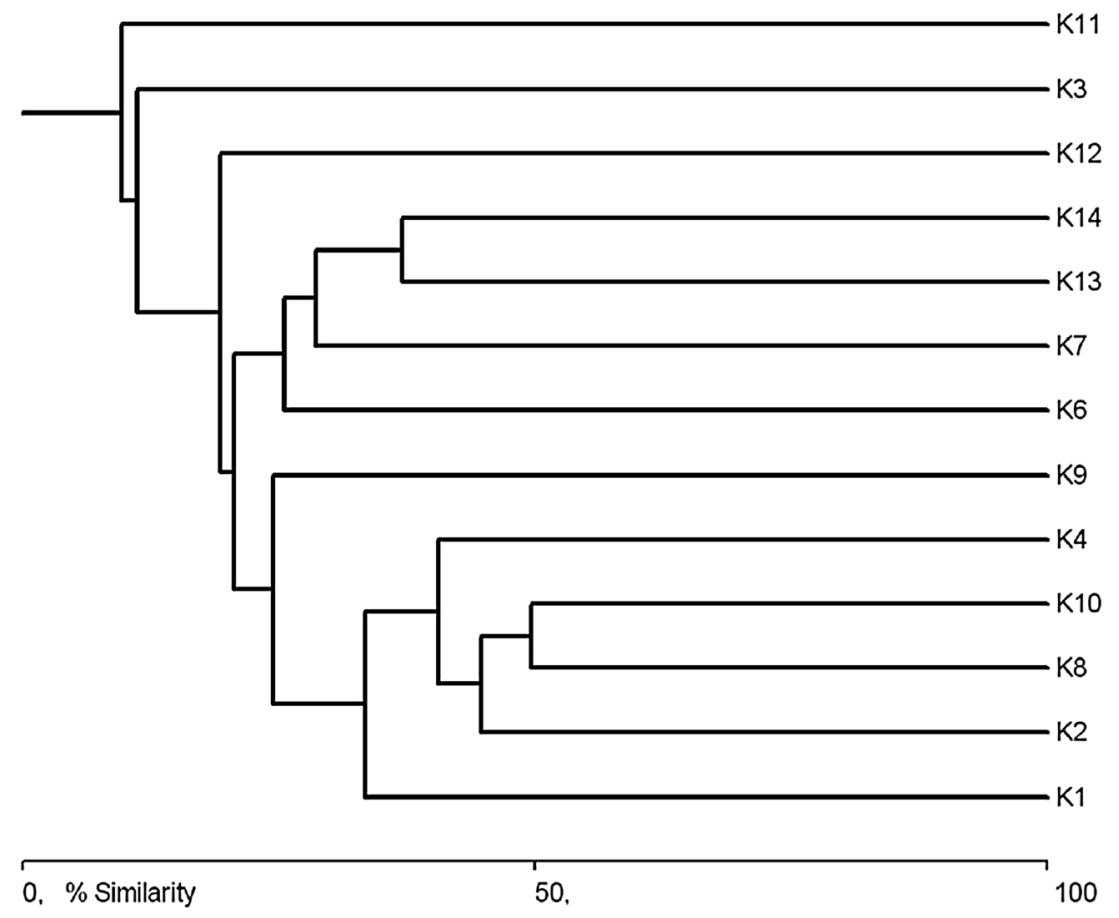

water bodies in the valley, this number should be regarded as very high.

The highest numbers of water mite individuals and species were caught in the oxbows (411 individuals, 55 species)-Table 2. The oxbows can be regarded as the most typical water bodies for river valleys, because they are formed as a consequence of natural processes associated with changes in the course of the river channel (Žadin 1950; quoted in Biesiadka 1974; Weihaupt 1977; Giardino and Lee 2012). Six oxbow lakes were taken into account in the study-more than the other types of water body (apart from the permanent ponds). This was because of their natural frequency of occurrence in the valley of the Krapiel. The large numbers of individuals and species caught were linked to the number of water bodies studied, but this was definitely not the only factor influencing the high qualitative and quantitative richness of the fauna of the oxbows. Seven permanent ponds were included in the study, but fewer individuals (324) and species (29) were caught in these ponds than in the oxbows. The high qualitative and quantitative richness of the fauna of the oxbows was influenced by the spatial factor, i.e., the location of these water bodies near the river. Owing to their spatial proximity, water mites could migrate between the river and the oxbows (Fig. 1), which increased the number of individuals and species in these water bodies. Studies by other authors (Biesiadka 1974, 1979; Cichocka 1996b; Biesiadka et al. 2004; Stryjecki 2009, 2010) confirm that oxbow lakes play a large, sometimes even dominant, role in shaping the fauna of river valleys.
In the dendrogram of faunal similarities between the different types of water body, we can see a pronounced tendency for water bodies other than springs to be grouped together, and clear separation of the fauna of the springs (Fig. 4). The highest similarity $(50.8 \%)$ was noted between the Hydrachnidia assemblages inhabiting the oxbows and riparian pools. The high similarity of the faunas of these two types of water body is unsurprising, as both riparian pools and oxbows can be regarded as having their origin in the river. Both types of water body are situated in close proximity to the river, and at times had a direct connection with it (Fig. 1). Hence, the formation of the fauna of oxbows and the formation of the flora of riparian pools are influenced by similar mechanisms, including the possibility of migration-direct (as adults via the water connection) or indirect (as larvae parasitizing aquatic insects). The fauna of the springs had a markedly distinct character, with very clear dominance of crenobionts and crenophiles (72.2\%). Species associated with springs were not found at all in most of the other water bodies studied (permanent ponds, sedge marshes, and flooded alder carrs), or were caught in very small numbers (in riparian pools and oxbows)-Table 2. The distinctiveness of the fauna of the springs is not at all surprising, as the fauna of springs is usually very characteristic, with a predominance of crenobionts and crenophiles and a small proportion of water mites from other synecological groups (Biesiadka and Kowalik 1978; Biesiadka et al. 1990; Smith 1991; Di Sabatino et al. 2003). 
Fig. 6 Dependence of water mite distribution on catchment characteristics: $R a$ roughness, $\mathrm{Cr}$ contagion, river $\mathrm{fa}$ river river river area, a cat cu catchment area from river source, $a$ wast wasteland area, $d$ source distance from river source, $d$ field distance from fields to river, $d$ build distance from buildings to river, $d$ mead distance from meadows to river, $d$ st wat distance from standing waters to river, $d$ fores distance from forest to river, $d$ shrub marsh distance from marshland to river, $d$ wast distance from wasteland to river gradient, a cat catchment area, $a$ distance from shrubs to river, $d$

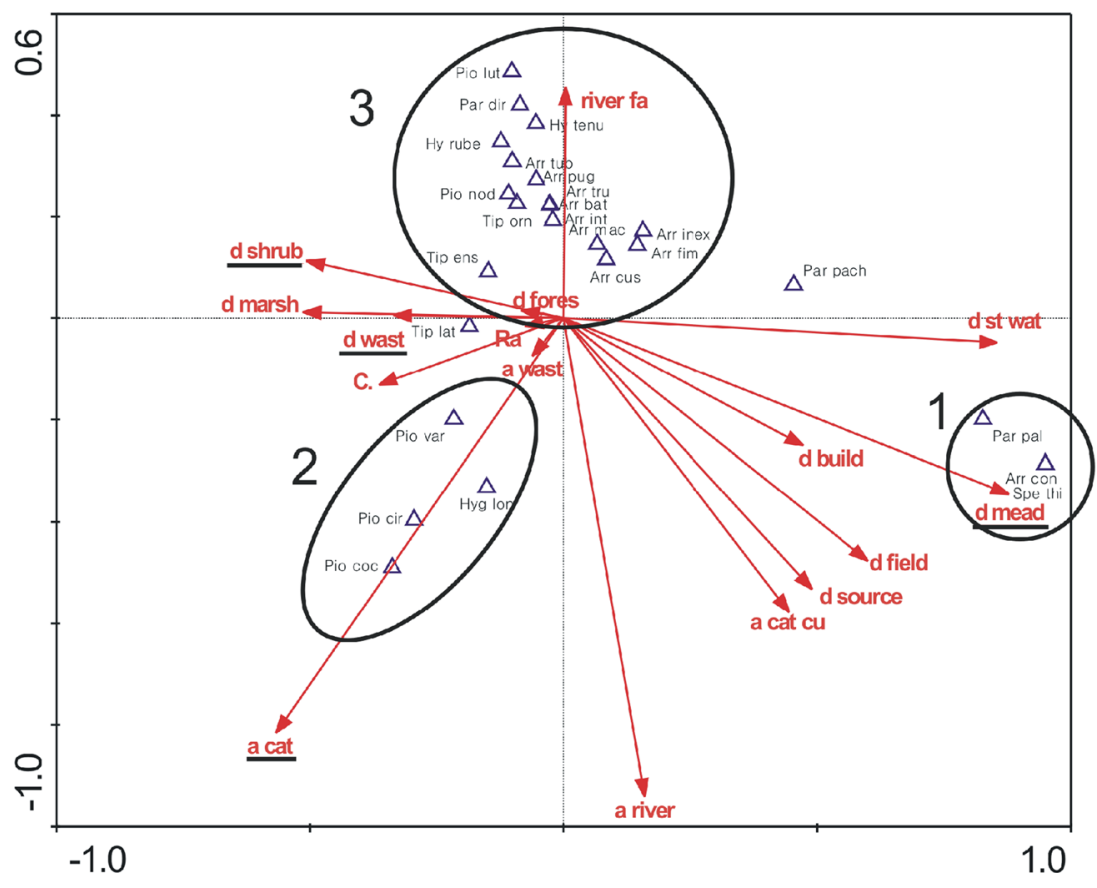

Fig. 7 Dependence of water mite distribution on the landscape characteristics of buffer zones

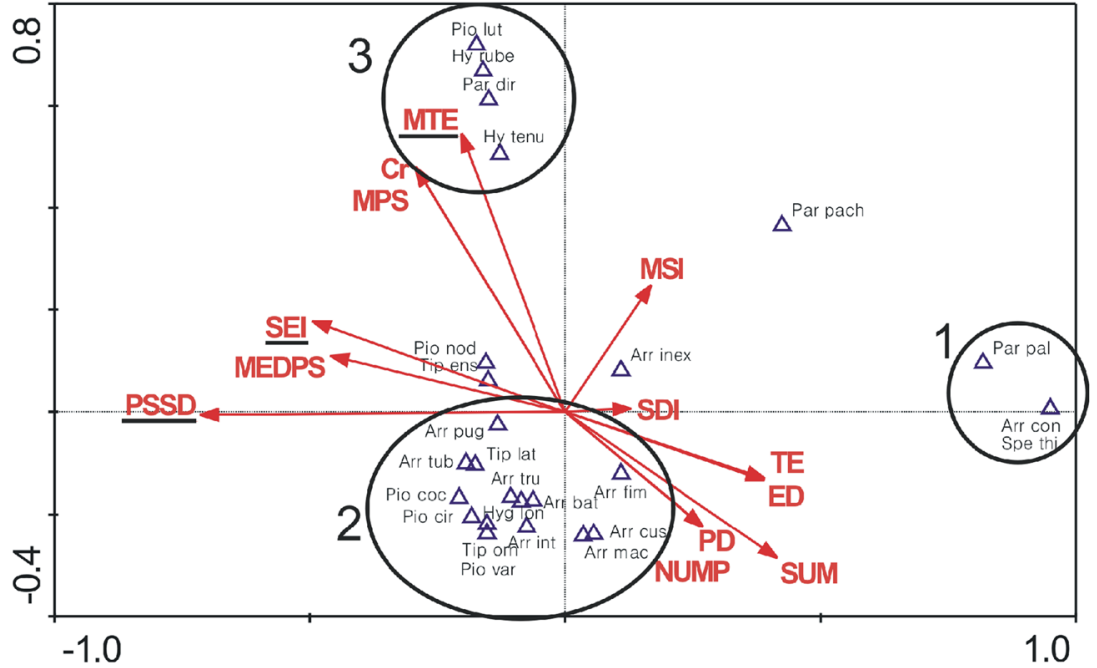

It is interesting to compare the fauna of the valley water bodies with that of the Krapiel River. As many as 61 species were common to the valley river bodies and the river, which is an indication of the strong link between the faunas of two separate and very different environments-a river and standing water bodies. The highest similarity was noted between the faunas of the river and the oxbow lakes $(33.1 \%, 39$ species in common). This similarity is unsurprising, as oxbows are genetically related to the river channel (Weihaupt 1977; Biesiadka 1979; Giardino and Lee 2012). Moreover, oxbows are usually situated near active river channels, and there is often the direct passage of water between them during high water (Fig. 1). Due to all of these factors (the origin of oxbows, proximity to river channels, and often a connection to the river), water mites can migrate between the river and the oxbows-directly, through the water connection, and indirectly, via transport of water mite larvae on aquatic insects (Smith and Oliver 1986; Gerecke 2002; Bohonak et al. 2004). The oxbows studied were flooded in the spring and became directly connected to the Krapiel River, which unquestionably contributed to the high faunal similarity and to the large number of species caught here (55 species-the most of all the water body types).

It is interesting that there were more species common to the valley river bodies and the lentic zone of the river (52) than to the lotic and lentic zones of the river itself (49 species in common). It can thus be concluded that in terms 


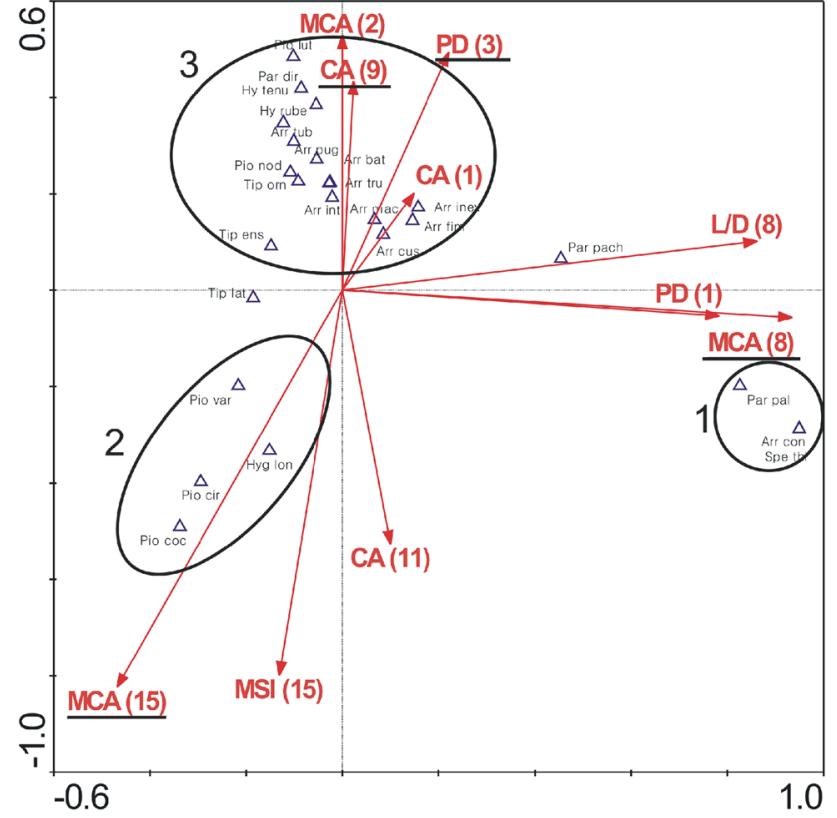

Fig. 8 Dependence of the water mite distribution on the characteristics of patches in buffer zones

of fauna, the lentic zone of the river has more in common with the valley river bodies than with the lotic zone of the river. At the same time, the large number of species common to the valley river bodies and the river (mainly the lentic zone) is indicative of the very strong influence of the valley water bodies (mainly oxbows) on the formation of the river fauna. Hence, the dominant direction of dispersal is the flow of species characteristic of standing water from the valley water bodies to the river (mainly to the lentic zone) (Fig. 1, bigger block arrows). Migration in the opposite direction-from the river to the valley water bodies-occurs to a much lesser degree (Fig. 1, smaller block arrows). The effect of the river on the fauna of the valley water bodies is minimal-river forms were found in very small numbers in the valley water bodies. Rheobionts and rheophiles were not found at all in the permanent ponds, and their percentage share in the other valley water bodies was very low (from 0.4 to $3.1 \%$ ). Only in the springs, which typologically are flowing water bodies, was their contribution somewhat greater $(7.1 \%)$. The minimal proportion of river forms in the standing water bodies of the valley was due to the fact that these species are far more stenotopic than the species caught in the valley river bodies, which are mostly eurytopic (Camacho and Valdecasas 1988). Rheobionts and rheophiles are unable to live outside of lotic ecosystems due to the absence of the main factor influencing their distribution, i.e., water flow, which is the fundamental factor influencing the distribution of river species (Biesiadka 1979; Kowalik 1981; Böttger and Martin 1995; van der Hammen and Smit 1996; Martin 1996, 1997). In contrast, species associated with standing water bodies constitute a permanent-and at times abundant-component of flowing water ecosystems, inhabiting mainly marginal pools of rivers with slower water flow and often abundant vegetation (Biesiadka 1970; Kowalik 1981; Kowalik and Biesiadka 1981; Bazan-Strzelecka 1986; Böttger and Hoerschelmann 1991; Cichocka 1996a, 2006; Biesiadka et al. 2004; Stryjecki 2009, 2010). In marginal pools, they find similar living conditions to those in their typical habitats-various types of standing water body.
Fig. 9 CCA analysis of the relationships between water mite species distribution and various physicochemical parameters

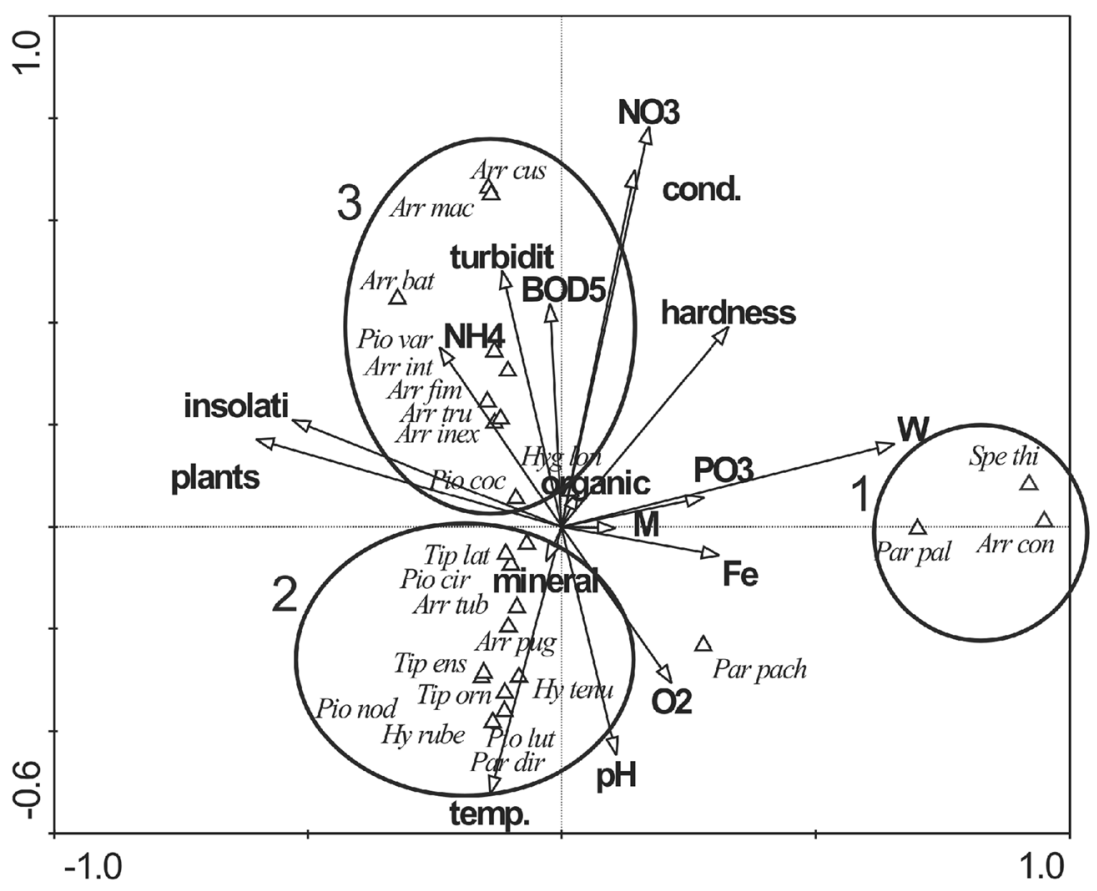


In the dendrogram of similarities between the faunas of different catchments, two large clusters can be seen (Fig. 5). Within the first cluster (catchments K1, K2, K8, $\mathrm{K} 10$, K4, and $\mathrm{K} 9$ ), the highest similarity was noted between the faunas of catchments K8 and K10 (49.7\%, Fig. 5). Different types of water bodies were present in these two catchments - two riparian pools in catchment K8 and two oxbow lakes in K10. As stated before, the highest faunal similarity was found between the riparian pools and the oxbows (50.8\%), as both types of water bodies contain water originating in the river. Hence, the high similarity of the faunas of these two types of water body contributed to the high similarity of the faunas of the catchments in which they were located. The fauna of catchment K2 was also associated with the pair of catchments K8-K10 (Fig. 5). Three permanent ponds were present in catchment $\mathrm{K} 2$ and two riparian pools were present in catchment K8. Though two different types of water bodies were present in these two catchments, their faunas were similar, as fairly high faunal similarity was found between the permanent ponds and the riparian pools $(44.7 \%)$. As in the example given above, the similarity of the faunas of catchments $\mathrm{K} 2$ and $\mathrm{K} 8+\mathrm{K} 10$ was a function of the similarity of the faunas of the water bodies located in these catchments. It can be stated that the similarity between the faunas of the catchments results from the similarity between the faunas of particular types of water bodies situated in these catchments. In other words, the presence of a particular type of water body had the strongest influence on the formation of a particular type of fauna in the catchments.

Comparisons of the dendrogram of landscape similarities (Fig. 3) with the dendrogram of faunal similarities (Fig. 5), the characteristics of sampled localities (Online Resource 1 in the ESM), and the landscape types in particular catchments (Table 1) show a lack of clear associations. The only exceptions are the catchment pair K8 and K10 and the catchment pair K13 and K14 (Fig. 3), which are also characterized by high faunal similarity (Fig. 5). The faunal similarity of these catchments results from the types of water body present in them, and thus the types of water mite fauna inhabiting them (K8 and K10-permanent eutrophic ponds; K13 and K14-temporary oxbows and a sedge marsh). It is significant that the fauna of water bodies, which are situated in an agricultural landscape, is markedly different from the fauna of similar water bodies located in catchments with a landscape dominated by forests. This finding may indicate that as well as the type of water body, the type of landscape may affect the formation of water mite fauna in particular types of waters. But further research is needed to confirm this thesis.

As there does not seem to be a very clear relationship between the character of the water mite fauna inhabiting the water bodies of the Krapiel River valley and that of the landscape of particular catchments, it is worth examining individual landscape factors in terms of their effect on water mite assemblages and particular species in them. Figure 6,7, and 8 show three groups of water mites. One of these groups (group 1), composed of the species Parathyas palustris, Sperchon thienemanii, and A. conicus, is present in all three figures. These are species typical of springs and are clearly separated from the remaining groups. Permanent springs in the valleys of lowland rivers are often formed in areas shaded by woody plants or shrubs, which prevents them from drying up and ensures a constant relatively low water temperature. Hence the clear relationship of the species present here with the distance between the meadows and the river channel (Fig. 6). It is much more difficult to explain the association of these species with the landscape characteristics of buffer zones. Figure 7 shows that these species are associated with a homogeneous landscape (with low SIE and PSSD values), while Fig. 8 shows a relationship with the size of orchard and plantation patches. While the relationship with orchards and plantations may be considered an unexplained artefact, landscape homogeneity seems to reduce the diversity of effects on springs, which, in combination with the susceptibility of springs to external influences (Biesiadka and Kowalik 1978; Biesiadka et al. 1990; Di Sabatino et al. 2003), affects the stability of these habitats and the preservation of their character as springs.

In Figs. 6 and 8 we can see two of the same groups of water mites-groups 2 and 3. These groups are differentiated, at least in part, by their food base, i.e., ostracods, copopods, and dipteran eggs and larvae in the case of group 2, and cladocerans and chironomid eggs and larvae for group 3 (Proctor and Pritchard 1989; Smith et al. 2001; Martin 2004), as well as by the species of their hostsOdonata, Chironomidae, and Culicidae in the case of group 2, and Chironomidae for group 3 (Smith and Oliver 1986; Smith et al. 2001; Zawal and Szlauer-Łukaszewska 2012; Zawal and Buczyński 2013). Figures 6 and 8 show that group 3 is associated with catchment size (which probably influences the eutrophication of the water bodies) and with the size of willow thickets in the buffer zones, where water bodies are formed that are colonized by these species. Group 2 is inversely associated with a smaller catchment area (the river gradient is statistically insignificant), as well as with the area of meadows and pastures and the patch density of thoroughfares. Figure 7 groups the water mites somewhat differently. Group 2 consists of species typical of astatic vernal water bodies, and is associated with the edge length of patches. The relationship of group 3 with the landscape metrics of buffer zones is much less pronounced, and we can observe only a small correlation with patches with short boundaries showing little variation. 
In the $\mathrm{CCA}$, we can see two sets of species associated with groups of various physicochemical factors of the water (Fig. 9). In the upper right-hand quarter of the diagram, we can see a group of habitat factors characteristic of permanent eutrophic ponds, i.e., ponds with well-developed aquatic vegetation, a high level of nutrients, and a muddy bottom. These habitat characteristics were mainly associated with small water body species of the genus Arrenurus. These species are common in both small eutrophic ponds and in the phytolittoral zones of lakes (Biesiadka and Kowalik 1991; Zawal 1992). In the lower left-hand quarter of the diagram, we can see a group of species for which an association with water temperature was noted. This group consists almost exclusively of species typical of astatic vernal water bodies. The association of these species with temperature, also demonstrated statistically, is somewhat misleading. The dependence of the species visible in the diagram on water temperature results from the fact that they are eurythermic (Smit and van der Hammen 2000), and their intensive development in the spring is caused by the sudden increase in temperature during the day in shallow astatic zones.

\section{Recapitulation and conclusions}

The species composition and abundance of the fauna caught in particular types of valley water bodies were strongly influenced by the spatial arrangement of the water bodies in the landscape (distribution of water bodies in the area and in relation to the river). An additional factor influencing the composition of the fauna was the origin of the water bodies.

As many as 61 species were common to the valley river bodies and the river Krapiel. The large number of common species is an indication of the very strong influence of the valley water bodies on the fauna of the river. In the interactions between the valley water bodies and the river the direction of migration from the former to the latter is clearly dominant. Migration in the reverse direction, from the river to the valley water bodies, takes place in a far lesser degree. This lack of symmetry in the directions of migration is due to the fact that water mites associated with standing water bodies are more eurytopic, and thus have greater ability to colonize new environments, while taxa characteristic of flowing water are more stenotopic.

Certain pairs of catchments in the dendrogram of faunal similarities correspond to pairs of catchments visible in the dendrogram of landscape similarities. Also, the fauna of water bodies situated in an agricultural landscape was also found to be markedly different from the fauna of similar water bodies located in catchments with a landscape dominated by forests. These observations suggest that the development of particular types of fauna in the catchments may be influenced not only by the presence of specific types of water body but also by specific types of landscape.

The CCA analysis of landscape variables showed an effect of certain landscape parameters on water mites. This should be regarded as an indirect influence, but as a consequence of these effects (e.g., on the hosts of water mite larvae or on the habitat characteristics of water bodies), they influence the formation of specific types of Hydrachnidia assemblages.

Acknowledgments Financial support was provided by the Ministry of Science and Higher Education, no. N305 222537. Reinhard Gerecke (Tübingen) checked and occasionally corrected the identification of selected questionable specimens.

Open Access This article is distributed under the terms of the Creative Commons Attribution 4.0 International License (http://crea tivecommons.org/licenses/by/4.0/), which permits unrestricted use, distribution, and reproduction in any medium, provided you give appropriate credit to the original author(s) and the source, provide a link to the Creative Commons license, and indicate if changes were made.

\section{References}

Bazan-Strzelecka H (1986) Water mites (Acari, Hydrachnellae) of Grabia River (in Polish). Acta Univ lodz Folia Zool Anthropol 4:59-69

Biesiadka E (1970) Water mites (Hydracarina) of the lower course of the Wełna River (in Polish). Fragm Faun 5:43-55

Biesiadka E (1974) Hydracarina of the River Raba and some of its tributaries. Acta Hydrobiol 16:31-50

Biesiadka E (1979) Water mites (Hydracarina) of the Pieniny Mountains (in Polish). Fragm Faun 24:97-173

Biesiadka E, Kowalik W (1978) Water mites (Hydracarina) of the sources of Roztocze. Acta Hydrobiol 20:11-34

Biesiadka E, Kowalik W (1991) Water mites (Hydracarina) as indicators of trophy and pollution in lakes. In: Dusbabek F, Bukwa V (eds) Modern acarology 1. Academia, Prague, pp 475-481

Biesiadka E, Cichocka M, Warzecha B (1990) Water mites (Hydracarina) of the spring in the Kraków-Częstochowa and Miechów uplands. Acta Hydrobiol 32:171-186

Biesiadka E, Cichocka M, Moroz MD (2004) Water mites (Hydrachnidia) from the Neman River (Belarus), some of its tributaries and riverine reservoirs. Fragm Faun 47:143-164

Bohonak AJ, Smith BP, Thornton M (2004) Distributional, morphological and genetic consequences of dispersal for temporary pond mites. Freshwat Biol 49:170-180

Böttger K, Hoerschelmann U (1991) Faunistics and ecology of water mites (Hydrachnidia, Actinedida, Actinotrichia, Acari) of the North German lowland creek Kossau. Limnological studies in Naturschutzgebied Kossautal (Schlezwig-Holstein) III (in German). Faunistisch-Ökologische Mitteilungen 6:219-228

Böttger K, Martin P (1995) Faunistic and ecological studies on the water mites (Hydrachnidia, Acari) of three small rivers of the North German Lowland, with special emphasis on rheobionten species. Limnological studies in Naturschutzgebied Kossautal (Schlezwig-Holstein) V (in German). Limnologica 25:61-72

Camacho AI, Valdecasas AG (1988) Spatial and biocenotic trends in the water-mite fauna of small ponds. Hydrobiologia 160:207-217 
Cichocka M (1996a) Water mites (Hydracarina) of the River Pasłeka (in Polish). Fragm Faun 39:179-205

Cichocka M (1996b) Water mites (Hydracarina) of the peat lands in Bagna Biebrzańskie (in Polish). Fragm Faun 39:207-221

Cichocka M (2006) Water mites (Hydrachnidia, Acari) in the running waters of the Masurian Landscape Park. Suppl Acta Hydrobiol $8: 33-53$

Cicolani B, Di Sabatino A (1991) Sensivity of water mites to water pollution. In: Dusbabek F, Bukwa V (eds) Modern acarology 1. Academia, Prague, pp 465-482

Delettre YR (2005) Short-range spatial patterning of terrestrial Chironomidae (Insecta: Diptera) and farmland heterogeneity. Pedobiologia 49:15-27

Delettre YR, Morvan N (2000) Dispersal of adult aquatic Chironomidae (Diptera) in agricultural landscapes. Freshwat Biol 44:399-411

Delettre Y, Tréhen P, Grootaert P (1992) Space heterogeneity, space use and short-range dispersal in Diptera: a case study. Landscape Ecol 6:175-181

Di Sabatino A, Gerecke R, Martin P (2000) The biology and ecology of lotic water mites (Hydrachnidia). Freshwat Biol 44:47-62

Di Sabatino A, Cicolani B, Gerecke R (2003) Biodiversity and distribution of water mites (Acari, Hydrachnidia) in spring habitats. Freshwat Biol 48:2163-2173

Galic N, Hengeveld GM, van den Brink PJ, Schmolke A, Thorbek P, Bruns E, Baveco JM (2013) Persistence of aquatic insects across managed landscapes: effects of landscape permeability on recolonization and population recovery. PLoS One 8:e54584. doi:10.1371/journal.pone.0054584

Gerecke R (2002) The water mites (Acari, Hydrachnidia) of a little disturbed forest stream in southwest Germany-a study on seasonality and habitat preference, with remarks on diversity patterns in different geographical areas. In: Bernini F, Nannelli R, Nuzzaci G, de Lillo E (eds) Acarid phylogeny and evolution. Adaptations in mites and ticks. Kluwer, Dordrecht, pp 69-89

Gerecke R, Schwoerbel J (1991) Water quality and water mites (Acari, Actinedida) in the upper Danube region. In: Dusbabek F, Bukwa V (eds) Modern acarology 1. Academia, Prague, pp 483-491

Giardino JR, Lee AA (2012) Evolution of oxbow lakes along the Brazos River. Final report, submitted to the Texas Water Development Board (Contract No. 0904830969). Department of Geology \& Geophysics, Texas A\&M University, College Station, pp 1-27

Kowalik W (1981) Water mites (Hydracarina) in the rivers of the Wieprz basin (in Polish). Ann UMCS C35:327-351

Kowalik W, Biesiadka E (1981) Occurrence of water mites in the River Wieprz polluted with domestic-industry sewage. Acta Hydrobiol 23:331-348

Kowalik W, Zawal A, Buczyńska E (2014) Water mites (Acari, Hydrachnidia) of the River Szum and Stream Krupiec in the Roztocze region. Acta Biol 21:75-89

Martin P (1996) Faunistic and ecological studies on the benthos and water mites (Hydrachnidia, Acari) of two streams of the North German Lowland (Ostcholsteinisches hills, Schleswig-Holstein) (in German). Faunistisch-Ökologische Mitteilungen 7:153-167

Martin P (1997) Faunistics and substrate preference of water mites (Hydrachnidia, Acari) of two characterized by fine mineral substrates streams in Schleswig-Holstein (in German). Faunistisch-Ökologische Mitteilungen 7:221-237

Martin P (2004) Water mites (Hydrachnidia, Acari) as predators in lotic environments. In: Weigmann G, Alberti G, Wohltmnn A, Ragusa S (eds) Acarine biodiversity in the natural and human sphere. Phytophaga 14:307-321

Mcaleece N, Lambshead PJD, Paterson GLJ (1997) Biodiversity Pro. The Natural History Museum, London
Meyer IM (1994) Species composition and seasonal dynamics of water mites (Hydracarina) in a mountain stream (Steina, Black Forest, southern Germany). Hydrobiologia 288:107-117

Myślińska E (2001) Laboratory examination of the soil (in Polish). PWN, Warszawa

Proctor H, Pritchard G (1989) Neglected predators: water mites (Acari: Parasitengona: Hydrachnellae) in freshwater communities. J N Am Benthol Soc 8:100-111

Richards C, Host G (1994) Examining land use influences on stream habitats and macroinvertebrates: a GIS approach. Water Resour Bull 30:729-738

Richards C, Johnson LB, Host G (1996) Landscape-scale influences on stream habitats and biota. Can J Fish Aquat Sci 53:295-311

Smit H, van der Hammen H (2000) Atlas of the Dutch water mites (Acari: Hydrachnidia) (in Dutch). Nederlandse Faunistische Mededelingen 13:1-266

Smith IM (1991) Water mites (Acari: Parasitengona: Hydrachnidia) of spring habitats in Canada. Mem Entomol Soc Can 155:141-167

Smith IM, Oliver DR (1986) The parasitic associations of larval water mites with imaginal aquatic insects, especially Chironomidae. Can Ent 108:1427-1442

Smith IM, Smith BP, Cook DR (2001) Water mites (Hydrachnidia) and other arachnids. In: Thorp JH, Covich AP (eds) Ecology and classification of North American freshwater invertebrates, 2nd edn. Academic, San Diego, pp 551-659

Stryjecki R (2009) Water mites (Acari, Hydrachnidia) of the Bug River valley between Włodawa and Kodeń. Teka Kom Ochr Kszt Środ Przyr-OL PAN 6:335-344

Stryjecki R (2010) Water mites (Acari: Hydrachnidia) of the northern part of Nadwieprzański Landscape Park. Teka Kom Ochr Kszt Środ Przyr-OL PAN 7:389-399

Stryjecki R, Kowalczyk-Pecka D (2013a) A synecological characterization of the water mite communities (Acari: Hydrachnidia) of the Tanew river in the Nad Tanwia reserve. Teka Kom Ochr Kszt Środ Przyr-OL PAN 10:407-416

Stryjecki R, Kowalczyk-Pecka D (2013b) A faunistic and ecological characterization of the water mites (Acari: Hydrachnidia) of the highly anthropologically transformed Mietiulka river in Polesie National Park. Environ Protect Nat Resour 1:11-15

ter Braak CJF (1986) Canonical correspondence analysis: a new eigenvector technique for ultivariate direct gradient analysis. Ecology 67:1167-1179

ter Braak CJF, Verdonschot PFM (1995) Canonical correspondence analysis and related multivariate methods in aquatic ecology. Aquatic Sci 57:255-289

van Der Hammen H, Smit H (1996) The water mites (Acari: Hydrachnidia) of streams in the Netherlands: distribution and ecological aspects on a regional scale. Neth $\mathrm{J}$ Aquat Ecol 30:175-185

Weihaupt JG (1977) Morphometric definitions and classifications of oxbow lakes, Yukon River basin, Alaska. Water Resour Res 13:195-196

Zawal A (1992) Water mites (Hydracarina) of three small lakes in the neighbourhood of Poznań. Acta Hydrobiol 34:157-174

Zawal A, Buczyński P (2013) Parasitism of Odonata by Arrenurus (Acari: Hydrachnidia) larvae in the Lake Świdwie, nature reserve (NW Poland). Acta Parasitol 58:486-495

Zawal A, Kowalik W (2013) Water mites of the Biała Łada and Czarna Łada rivers in the Lublin region. Ann UMCS C93:117-125

Zawal A, Szlauer-Łukaszewska A (2012) Water mite parasites (Hydrachnidia) of odonates from the nature reserve "Jezioro Szare”, northwestern Poland. Odonatologica 41:267-275 